\title{
VALIDITY AND RELIABILITY OF THE NICU PARENTAL BELIEFS SCALE FOR PARENTS IN TURKEY
}

\author{
Funda Kardaş Özdemir ${ }^{1}$ and Dilek Küçük Alemdar ${ }^{2}$ \\ ${ }^{1}$ Health Sciences Faculty, Kafkas University, Kars, Turkey; \\ ${ }^{2}$ Health Sciences Faculty, Giresun University, Giresun, Turkey
}

\begin{abstract}
SUMMARY - This methodological study was conducted for Turkish adaptation of the Neonatal Intensive Care Unit Parental Beliefs Scale (NICU PBS). The study sample consisted of 136 mothers and 97 fathers who had agreed to participate in the study. Turkish linguists were consulted to test the linguistic validity of the scale. Explanatory factor analysis was performed for construct validity of the scale, which indicated that the 18 items in the scale had a three-factor structure, explaining a maximum of $70.24 \%$ of total variance. Considering factor loadings, the factor load values ranged from 0.614 to 0.806 . Concerning reliability of the scale, the item-total score correlation values were found to be $0.54-0.78$, and the Cronbach's alpha was 0.90 . Accordingly, the Turkish version of NICU PBS can be considered valid and reliable.
\end{abstract}

Key words: Intensive care units, neonatal; Parenting - psychology; Reproducibility of results; Surveys and questionnaires; Turkey

\section{Introduction}

Each year, about 20 million babies are born in the world and about 1 million babies are born in Turkey. The percentage of infants with birth weight below $2500 \mathrm{~g}$ varies between $3 \%$ and $30 \%$ depending on the country, whereas $7 \%-15 \%$ of infants born in Turkey have low-birth-weight (LBW) and two-thirds of these infants are preterm ${ }^{1}$. According to the study conducted by the Turkish Neonatal Society, $26 \%$ of infant mortality is associated with preterm labor. It is reported that perinatal mortality is $5-10$ times higher in LBW infants compared to normal neonates ${ }^{2}$. The survival rate of preterm and LBW infants has increased thanks to technological advancements in neonatal intensive care units (NICU) and decreased mortality has been accompanied by increased morbidity. It is therefore necessary to monitor LBW infants frequently and

Correspondence to: Assist. Prof. Funda Kardaș Özdemir, PhD, Health Sciences Faculty, Kafkas University, Kars, Turkey

E-mail: fkardas@gmail.com

Received March 13, 2017, accepted May 23, 2017 for extended periods of time $e^{1-3}$. Referring infants to the NICU again for any reason is a source of stress and anxiety for families. It affects development of both parental and infant abilities. Environmental factors related to the intensive care setting, and the infant's vulnerability and immaturity may produce negative results. The NICU environment causes parents to experience stress ${ }^{4,5}$. Units are usually crowded, noisy, equipped with advanced technology, highly illuminated and hot ${ }^{4}$.Families usually neglect to visit the NICU and meet the staff in the prenatal care process. The behaviors and the language of the staff are unfamiliar to parents who suddenly find themselves in the intensive care environment, which causes them to isolate themselves ${ }^{6}$.

Nurses have a significant role in mitigating the negative effects of the infant's hospitalization in the NICU on the family and supporting the family physically, emotionally, intellectually and socially ${ }^{7,8}$. Nurses should predict how the family will be affected by the infant's hospitalization in the NICU, determine the infant's requirements and support parents at every 
stage $\mathrm{e}^{7,9,10}$. The physical environment of the NICU is a source of stress for families and creates certain obstacles, e.g., the incubator isolates the infant; the appearance of the infant, and the noise and lights in the environment can provoke anxiety; medical equipment means that families are distant from the infant; and families feel helpless since they cannot control these devices and think that they themselves may hurt the infant $^{6,11}$. Being separated from their child, the change in the role that parents play, uncertainty about the infant's status and fear caused by the lack of knowledge about how to take care of the infant at home are factors that increase stress ${ }^{5}$. Since the infant hospitalized in the NICU becomes the focal point, the parental roles assumed by the parents change or begin not to function as usual. While one of the parents deals with the care of the infant hospitalized in the NICU, the responsibility of the other parent for taking care of any other children in the family increases and workplacerelated responsibilities are interrupted ${ }^{12}$. Negative factors such as increased responsibility, disruption in the care of other family members at home and absence from work lead to quarrels between spouses and with other family members ${ }^{6}$.

It is very important that nurses act sensitively with regard to the perception of parents about their infant and the intensive care environment. Personnel working with hospitalized infants may lose their sensitivity to how parents perceive their infant and intensive care environment.

In such cases, fear and anxiety experienced by parents will increase even further. Nurses must implement nursing interventions, which will allow them to cope with fear and anxiety ${ }^{13}$. In order to help family members, neonatal nurses must learn what the primary requirements of families are and understand what their behaviors mean because communication problems between family members and health workers increase difficulties of parents and other family members even further. If nurses manage to understand the problems experienced between family members and to personally communicate with them, these problems will diminish and family members will have easier time adapting to the process ${ }^{9,11}$. Parents who feel safe and in a familiar environment begin to communicate with their infants earlier. The stress experienced by parents may be associated with their lack of knowledge and unhelpful hospital rules, which negatively affect the relationship between the parent and the infant. For this reason, it is very important to communicate with the family and inform them about the rules that the unit has ${ }^{14,15}$.

Among the most significant factors for predicting outcomes in preterm children is that interaction between parents and infants occurs at an early stage. A number of researchers have proposed that this may play a mediating role between the behavioral and developmental outcomes of the infants and the parents' anxiety ${ }^{16}$. What parents believe their role to be and how it affects their children's vulnerabilities, characteristics and behavior have also been related to stress, anxiety and depression and can often last long after discharge from the NICU ${ }^{17}$. It seems that most studies in Turkey on the effects of infant hospitalization in the NICU on the family employ the survey method. A valid and reliable measurement tool for assessment of cognitive beliefs of parents is not available in our country. It is necessary that nurses who work with a family closely and for extended periods of time determine how parents are affected by their infant's hospitalization in the intensive care unit, and plan and implement nursing interventions to minimize any possible effects ${ }^{7,9}$. This study aimed to assess the reliability and validity of the Turkish version of the Neonatal Intensive Care Unit Parental Beliefs Scale (NICU PBS), thereby to provide an assessment tool to examine the effects of infant hospitalization on their parents.

\section{Materials and Method}

\section{Design}

This study was planned as a methodological research carried out in order to adapt the NICU PBS into Turkish. The study population consisted of parents fulfilling the selection criteria, who had infants receiving treatment and care in the NICU of a state hospital between July 10, 2014 and September 30, 2015 . In the scale validity and reliability studies, it is suggested that the sample size be 5-10 times the number of items in the scale and it is reported that at least 30 data pairs must be available for test-retest assessment ${ }^{18,19}$. In this study, the number of participants was about 7 times the number of items for mothers $(n=136)$ and about 6 times the number of items for fathers $(n=97)$. The NICU PBS was filled in completely be- 
tween 4 and 8 days after admission to the NICU. It was filled in independently by both the mothers and the fathers. Those eligible to participate were mothers and fathers aged 18 years and older who were able to speak and read Turkish, who had not previously had another child admitted to the NICU, and whose children fulfilled the following criteria: (a) gestational age 28-37 weeks inclusive, (b) birth weight less than 3000 g, (c) anticipated survival, (d) being a single birth, (e) having no severe congenital anomalies, and (f) being born at the sites of the study.

The sample for this psychometric evaluation consisted of 136 mothers aged between 18 and 39 years $(\mathrm{M}=27.40, \mathrm{SD}=5.01)$ and 97 fathers aged between 18 and 42 years $(\mathrm{M}=30.7, \mathrm{SD}=6.39) ; 9.4 \%$ of the mothers and $12.8 \%$ of the fathers had high school education; $3.2 \%$ of the mothers and $2.4 \%$ of the fathers had a history of stressful experience in the previous year; $41.2 \%$ of the neonates were female and $59.8 \%$ were male. The mean gestational age of the premature infants was 32.6 weeks ( $\mathrm{SD}=3.21$, range $=28-37$ weeks), and the infants' birth weight ranged from 910 to $2.550 \mathrm{~g}(\mathrm{M}=1810.43$ $\mathrm{g}, \mathrm{SD}=621.57)$. The mean total length of stay in the NICU was 19.71 days ( $\mathrm{SD}=7.28$, range $=5-27$ days), the mean Apgar score was 6.7 at 1 minute, and $82.2 \%$ of the infants were diagnosed with respiratory distress syndrome and prematurity.

\section{Data collection}

The Parent-Baby Information Form is made up of the following 11 criteria: parental age, educational level, occupation and stressful events experienced in the last 12 months; infant postnatal age, gender, gestational age, birth weight, Apgar score and diagnosis.

Neonatal Intensive Care Unit Parental Beliefs Scale (NICU PBS): the scale was developed by Melnyk et al. ${ }^{20}$. The NICU PBS consists of three subscales (Parental Role Confidence, Parent-Baby Interaction and Knowledge of the NICU) and 18 items in total. Each item is scored from 1 ("strongly disagree") to 5 ("strongly agree"). The minimum score is 18 and the maximum score is 90 . A high score indicates that the mother and the father have positive parental beliefs.

\section{Language validity}

For linguistic validity of the NICU PBS, one linguist and two faculty members translated the original
English scale into Turkish. After that, another linguist translated the Turkish version of the scale back into English. Items that contained discrepancies were retranslated and back-translated again until the translation was satisfactory ${ }^{21}$. All the versions were evaluated by the authors and the final version was then formed. A Turkish language expert checked the Turkish version of the scale.

\section{Content validity}

Opinions of experts were received for the content validity of the NICU PBS. To this end, the draft Turkish form of the scale was submitted to six faculty members after the translation had been completed. The items were assessed by the experts according to the statements below: "Not suitable" (1 point); "The item should be changed to make it suitable" (2 points); "Suitable, but requires minor changes" ( 3 points); and "Very suitable" (4 points).

\section{Pilot implementation}

After studies for the linguistic validity of the scale, it is recommended that the scale be administered to a group of 10-20 individuals who possess characteristics similar to participants but are not included in the sample. The scale was given its final version after correspondence analysis and expert evaluations, and pilot implementation was performed with twelve mothers and ten fathers. It was decided to administer the scale to a sample of sufficient size for validity and reliability testing since no negative feedback had been received. These mothers and fathers were not included in the sample.

\section{Statistical analysis}

Data were analyzed using an appropriate statistical software program, SPSS, version 18.0 for Windows (SPSS Inc., Chicago, IL, USA). The analyses used were as follows: expert opinions were assessed using the Kendall $\mathrm{W}$ test for content validity of the scale. Factor analysis, Kaiser-Meyer-Olkin (KMO) test and Barlett's test were performed for construct validity. The Pearson Product-Moment Correlation Coefficient, item-total score correlation, subscale item-total score correlation and subscale-total score coefficient were calculated for reliability. Cronbach analysis was used to test internal consistency as another reliability analysis. 
Table 1. Neonatal Intensive Care Unit Parental Beliefs Scale (NICU PBS) factor analysis results

\begin{tabular}{|c|c|c|}
\hline Item & Factor load & Factor \\
\hline $\begin{array}{l}\text { Item 1. I know what characteristics and behaviors are common in premature babies } \\
\text { hospitalized in the NICU. }\end{array}$ & 0.806 & \multirow{7}{*}{$\begin{array}{l}\text { Factor 1: } \\
\text { Parental Role } \\
\text { Confidence }\end{array}$} \\
\hline $\begin{array}{l}\text { Item 2. I am sure that what I do for my baby will be what is best to help } \\
\text { him/her deal with being in the NICU. }\end{array}$ & 0.720 & \\
\hline Item 3. I feel comfortable in caring for my baby in the NICU. & 0.614 & \\
\hline $\begin{array}{l}\text { Item 4. I know what characteristics and behaviors to expect in my baby while } \\
\text { he/she is in the NICU. }\end{array}$ & 0.625 & \\
\hline $\begin{array}{l}\text { Item } 5 . \text { I am sure about what things I can do to best help my baby get through } \\
\text { the NICU experience. }\end{array}$ & 0.682 & \\
\hline $\begin{array}{l}\text { Item } 6 . \text { I am sure that I can meet my baby's emotional needs while he/she is } \\
\text { in the NICU. }\end{array}$ & 0.689 & \\
\hline $\begin{array}{l}\text { Item } 7 \text {. I know why my baby has the characteristics and behaviors that he/she does } \\
\text { in the NICU. }\end{array}$ & 0.802 & \\
\hline $\begin{array}{l}\text { Item } 8 \text {. I feel confident in telling the nurses and doctors about what will best help } \\
\text { my baby while he/she is in the NICU. }\end{array}$ & 0.685 & \multirow{8}{*}{$\begin{array}{l}\text { Factor 2: } \\
\text { Parent-Baby } \\
\text { Interaction }\end{array}$} \\
\hline Item 9. I am clear about how to help take care of my baby in the NICU. & 0.709 & \\
\hline $\begin{array}{l}\text { Item } 10 . \text { I know how my baby will probably respond to me while he/she is } \\
\text { in the NICU. }\end{array}$ & 0.651 & \\
\hline $\begin{array}{l}\text { Item 11. I am sure about how my emotions will affect my baby while he/she is } \\
\text { in the hospital. }\end{array}$ & 0.616 & \\
\hline $\begin{array}{l}\text { Item } 12 . \text { I am clear about how my baby will react when he/she is getting too much } \\
\text { stimulation in the NICU. }\end{array}$ & 0.672 & \\
\hline $\begin{array}{l}\text { Item } 13 . \text { I am sure about the things that I can do to make my baby feel most secure } \\
\text { while he/she is in the NICU. }\end{array}$ & 0.716 & \\
\hline $\begin{array}{l}\text { Item } 14 . \text { I know how my baby's appearance and behaviors are different from } \\
\text { a full-term baby's appearance and behaviors. }\end{array}$ & 0.721 & \\
\hline Item $15 . \mathrm{I}$ know the best times to communicate with or interact with my baby. & 0.733 & \\
\hline $\begin{array}{l}\text { Item } 16 . \text { I am confident in asking the doctors and nurses questions about my baby's } \\
\text { medical condition. }\end{array}$ & 0.708 & \multirow{3}{*}{$\begin{array}{l}\text { Factor 3: } \\
\text { Knowledge } \\
\text { of the NICU }\end{array}$} \\
\hline Item $17 . \mathrm{I}$ know what my baby will do when he/she is stressed. & 0.671 & \\
\hline $\begin{array}{l}\text { Item } 18 . \text { I am clear about what my baby will look or act like when he/she is ready to } \\
\text { communicate with me. }\end{array}$ & 0.769 & \\
\hline Explained variance & \multicolumn{2}{|l|}{$70.24 \%$} \\
\hline Total & \multicolumn{2}{|l|}{$70.24 \%$} \\
\hline
\end{tabular}

\section{Ethical considerations}

For adaptation of the original NICU PBS into Turkish, the approval of the patent holder of the scale, i.e. Bernadette Mazurek Melnyk, $\mathrm{PhD}$, was obtained via e-mail. The necessary permissions were obtained from the relevant institution for the study. The objective of this study was communicated to the families of the preterm infants included and their questions were answered. The parents provided a written informed consent, and were assured that the information pro- vided would not be used for any other purposes and would remain confidential. This study therefore fully met the principles of ensuring informed consent, voluntariness, protecting the privacy and individual rights of human subjects, and was conducted fully respecting ethical principles.

\section{Results}

As a result of the factor analysis, the KMO coefficient was 0.880 and Barlett's test value was $\chi^{2}=461.83$, 
Table 2. The Neonatal Intensive Care Unit Parental Beliefs Scale (NICU PBS) subscale item and subscale score-total score correlation coefficients and Cronbach's alpha values for the whole scale and subscales

\begin{tabular}{|c|c|c|c|c|}
\hline Subscales and items & $\mathrm{M}$ & $\mathrm{SD}$ & $\mathrm{R}$ & $\mathrm{p}$ \\
\hline \multicolumn{5}{|l|}{ 1. Subscale: Parental Role Confidence } \\
\hline $\begin{array}{l}\text { Item 2. I am sure that what I do for my baby will be what is best to help } \\
\text { him/her deal with being in the NICU. }\end{array}$ & 2.23 & 1.30 & 0.71 & 0.000 \\
\hline Item 3. I feel comfortable in caring for my baby in the NICU. & 3.25 & 1.16 & 0.72 & 0.000 \\
\hline $\begin{array}{l}\text { Item } 5 . \text { I am sure about what things I can do to best help my baby get through } \\
\text { the NICU experience. }\end{array}$ & 3.25 & 1.14 & 0.54 & 0.000 \\
\hline $\begin{array}{l}\text { Item 6. I am sure that I can meet my baby's emotional needs while he/she is } \\
\text { in the NICU. }\end{array}$ & 2.87 & 1.08 & 0.68 & 0.000 \\
\hline $\begin{array}{l}\text { Item } 8 \text {. I feel confident in telling the nurses and doctors about what will best } \\
\text { help my baby while he/she is in the NICU. }\end{array}$ & 3.25 & 1.34 & 0.78 & 0.000 \\
\hline Item 9. I am clear about how to help take care of my baby in the NICU. & 3.13 & 1.26 & 0.76 & 0.000 \\
\hline $\begin{array}{l}\text { Item } 10 . \text { I know how my baby will probably respond to me while he/she is } \\
\text { in the NICU. }\end{array}$ & 2.95 & 1.14 & 0.70 & 0.000 \\
\hline \multicolumn{5}{|l|}{ 2. Subscale: Parent-Baby Interaction } \\
\hline $\begin{array}{l}\text { Item } 11 . \text { I am sure about how my emotions will affect my baby while he/she is } \\
\text { in the hospital. }\end{array}$ & 2.67 & 1.20 & 0.61 & 0.000 \\
\hline $\begin{array}{l}\text { Item } 12 . \text { I am clear about how my baby will react when he or she is getting too } \\
\text { much stimulation in the NICU. }\end{array}$ & 2.91 & 1.15 & 0.71 & 0.000 \\
\hline $\begin{array}{l}\text { Item } 13 . \text { I am sure about the things that I can do to make my baby feel most } \\
\text { secure while he/she is in the NICU. }\end{array}$ & 2.96 & 1.11 & 0.72 & 0.000 \\
\hline $\begin{array}{l}\text { Item } 14 \text {. I know how my baby's appearance and behaviors are different from } \\
\text { a full-term baby's appearance and behaviors. }\end{array}$ & 3.02 & 1.33 & 0.73 & 0.000 \\
\hline Item $15 . \mathrm{I}$ know the best times to communicate with or interact with my baby. & 2.77 & 1.06 & 0.70 & 0.000 \\
\hline $\begin{array}{l}\text { Item } 16 . \text { I am confident in asking the doctors and nurses questions about my } \\
\text { baby's medical condition. }\end{array}$ & 3.42 & 1.31 & 0.62 & 0.000 \\
\hline Item 17. I know what my baby will do when he/she is stressed. & 2.83 & 1.15 & 0.70 & 0.000 \\
\hline $\begin{array}{l}\text { Item } 18 \text {. I am clear about what my baby will look or act like when } \\
\text { he/she is ready to communicate with me. }\end{array}$ & 2.88 & 1.14 & 0.73 & 0.000 \\
\hline \multicolumn{5}{|l|}{ Subscale: Knowledge of the NICU } \\
\hline $\begin{array}{l}\text { Item 1. I know what characteristics and behaviors are common in premature } \\
\text { babies hospitalized in the NICU }\end{array}$ & 2.12 & 1.32 & 0.77 & 0.000 \\
\hline $\begin{array}{l}\text { Item } 4 . \text { I know what characteristics and behaviors to expect in my baby while } \\
\text { he/she is in the NICU. }\end{array}$ & 3.15 & 1.22 & 0.74 & 0.000 \\
\hline $\begin{array}{l}\text { Item } 7 . \text { I know why my baby has the characteristics and behaviors that } \\
\text { he/she does in the NICU. }\end{array}$ & 2.93 & 1.21 & 0.65 & 0.000 \\
\hline
\end{tabular}

$\mathrm{p}=0.000$. The Parental Role Confidence subscale explained $36.08 \%$ of the total variance, the Parent-Baby Interaction subscale explained $24.71 \%$ of the total variance, and the Knowledge of the NICU subscale explained $9.44 \%$ of the total variance; $70.24 \%$ of the variance was explained in total. As a result of the confirmatory factor analysis, the scale was found to have three factors: Parental Role Confidence, Parent-Baby
Interaction and Knowledge of the NICU. Factor load values ranged from 0.614 to 0.806 for the Parental Role Confidence subscale, from 0.614 to 0.733 for the Parent-Baby Interaction subscale, and from 0.669 to 0.671 for the Knowledge of the NICU subscale. Factor loads of the scale are shown in Table 1. In terms of adaptation indicators of the model tested with the confirmatory factor analysis, it was observed 
Table 3. The Neonatal Intensive Care Unit Parental Beliefs Scale (NICU PBS) alpha values for the whole scale and subscales

\begin{tabular}{|l|l|l|l|}
\hline Scale & $\begin{array}{l}\text { Mother } \\
(\mathrm{n}=136)\end{array}$ & $\begin{array}{l}\text { Father } \\
(\mathrm{n}=97)\end{array}$ & Total \\
\hline Parental Role Confidence & 0.83 & 0.81 & 0.84 \\
Parent-Baby Interaction & 0.83 & 0.80 & 0.82 \\
Knowledge of the NICU & 0.79 & 0.74 & 0.77 \\
NICU PBS & 0.91 & 0.88 & 0.90 \\
\hline
\end{tabular}

that the $\chi^{2}$ value $\left(\chi^{2}=181.04 ; \mathrm{SD}=13.45 ; \mathrm{p}=0.000\right)$ was significant.

Considering subscale items and subscale total score correlation, reliability coefficients of the items ranged from 0.54 to 0.78 for the Parental Role Confidence subscale, from 0.61 to 0.73 for the Parent-Baby Interaction subscale, and from 0.65 to 0.77 for the Knowledge of the NICU subscale, indicating that the correlation was positive and very significant. Considering total scale scores and correlation of the subscales of the scale, reliability coefficients ranged from $\mathrm{r}=0.54$ to $\mathrm{r}=0.78$; the correlation was positive, strong and highly significant $(\mathrm{p}<0.001)$ (Table 2$)$.

The analysis performed to test internal consistency, which is one of the reliability indicators of the NICU PBS and its subscales, showed that the Cronbach's alpha reliability coefficient ranged from 0.77 to 0.84 , and total Cronbach's alpha for the whole scale was found to be 0.90 (Table 3).

\section{Discussion}

Neonates who receive technological support and treatment at the highest level in the NICU have an increased survival rate. However, these infants and their parents may stay in the NICU for days, weeks and even months, which has significant psychological and financial outcomes. These outcomes disrupt mental health of parents (e.g., anxiety, depression, posttraumatic stress disorder, dysfunctional parenting, negative parent-baby bonding) and coping mechanisms are not effective ${ }^{22,23}$. The NICU is a source of excessive stress for parents, with anxiety-inducing medical equipment, unfamiliar personnel, restrictive hospital policies, and the infant's appearance and behaviors, which negatively affect parental roles and parent-baby interaction. The inability to begin early par- ent-baby interaction in particular is one of the expected outcomes of premature labors. The beliefs of parents regarding their roles and how they should behave, and the characteristics and fragility of neonates are associated with stress, anxiety and depression, which usually continue after discharge from the NICU $5,7,10,17$.

The main properties required for a scale to be standardized are validity and reliability. Validity is the ability of a measurement tool to measure the desired characteristic or state. There are many criteria for validity testing ${ }^{18,19,24}$. Linguistic validity, content validity and construct validity were investigated to assess the validity of the scale. As a result of expert opinions, it can be said that the Turkish form of the NICU PBS is an appropriate measurement tool in terms of linguistic and content validity.

Factor analysis was performed to determine the construct validity of the NICU PBS. In order to investigate the factor structure of the scale, first the KMO test, which reveals sample adequacy, and then Barlett's test, which reveals whether the scale is suitable for factor analysis, were carried out and the results were found to be significantly suitable for factor analysis $\left(\mathrm{KMO}=0.880 \text { and } \chi^{2}=461.83, \mathrm{p}=0.000\right)^{19,25}$.

As a result of the confirmatory factor analysis that was carried out in order to reduce relations between concepts to basic factors and to reveal the scale structural properties, the scale was found to have three factors: Parental Role Confidence, Parent-Baby Interaction and Knowledge of the NICU. It has also been reported in the study conducted by Melnyk et al. that the scale has a three-factor structure ${ }^{20}$. Factor load values ranged from 0.614 to 0.806 for the Parental Role Confidence subscale, from 0.614 to 0.733 for the Parent-Baby Interaction subscale, and from 0.669 to 0.671 for the Knowledge of the NICU subscale. It is specified in the literature that the factor load must be at least 0.40 , and since the factor load of the items in the NICU PBS was over 0.40, no item was removed from the scale ${ }^{19,24,26}$. The Parental Role Confidence subscale explained $36.08 \%$ of the total variance, the Parent-Baby Interaction subscale explained $24.71 \%$ of the total variance, and the Knowledge of the NICU subscale explained $9.44 \%$ of the total variance. A maximum of $70.24 \%$ of the total variance was explained. Considering total scale scores and correlation of the subscales of the scale, reliability coefficients ranged from $r=0.54$ to $r=0.78$, and the correlation was positive, 
strong and highly significant. On the other hand, Melnyk et al. found the test-retest correlation to be between 0.84 and $0.92^{20}$.

Internal consistency means that each subscale of the scale measures the same property and shows the same structure ${ }^{18}$ The item-total score correlation is expected to be at least 0.30 for internal consistency. The item-total score correlation was over 0.30 for the whole scale, and the subscales found in the internal consistency and item reliability analysis showed that the whole scale and its subscales measured the same property. It is stated in the literature that the Cronbach's alpha value must be determined for the internal consistency and reliability of Likert-type scales ${ }^{18,19,24}$. The Cronbach's alpha coefficient shows the internal consistency and homogeneity of scale items. In this respect, it is reported that the lower limit of Cronbach's alpha coefficient is 0.70 and that reliability increases as the value approaches $1^{18,19,24,25}$. In the present study, the Cronbach's alpha reliability coefficient ranged from 0.77 to 0.84 for subscales and the total Cronbach's alpha for the whole scale was 0.90. In the study conducted by Melnyk et al., the reliability for the total scale and subscales was found to be high and Cronbach's alpha value ranged from 0.75 to 0.91 . However, high Cronbach's alpha coefficients indicated that the reliability of the scale and subscales in total were very good ${ }^{20}$.

Higher degrees of stress are often manifested by parents who have unrealistic expectations and beliefs related to parenting and their child's development. This can occur as a result of pressure to attain unachievable targets and goals ${ }^{27}$.In a way that is consistent with the findings of previous studies, a high degree of confidence among parents seems to provide protection against stress ${ }^{5}$, depression ${ }^{21}$ and anxiety ${ }^{13}$. These results indicated the NICU PBS to be a reliable measure that could be successfully employed with the parents of premature infants in the NICU. In addition, it may also be helpful in terms of identifying individual parents of these children at high risk of suffering from anxiety, depression and stress.

\section{Conclusion}

In this study, the Turkish form of the 18-item NICU PBS was found to have high validity and reli- ability. For this reason, it is recommended to be used in order to assess cognitive beliefs of parents of premature infants about the NICU. It may also be used to predict stress, anxiety and depression in parents.

In accordance with the results obtained, it is important for the improvement of parent-infant health that nurses working in the NICU develop and implement nursing interventions to support parents, meet their need for information and empower them. Family members experience a high level of fear and stress. If nurses realize what family members need, understand their emotional responses and help the family cope with the crisis, it will greatly contribute to both the infant's and the parents' health.

\section{Acknowledgments}

We are very grateful to the parents who participated in this study and to the nurses employed at the NICU.

\section{References}

1. Çoban A, İnce Z, Uğur Baysal S. Social pediatrics, newborns and diseases. In: Cantez T, Eker Ömeroğlu R, Baysal US, Oğuz F (Eds.). Child Health and Diseases. İstanbul: Nobel Tip Kitabevleri, 2003;33-72, 294-301. (in Turkish)

2. Y1ldiz S. Neonatal nursing in the world and our country. In: Dağoğlu T, Görak G (Eds.). Basic Neonatology and Nursing Principles, $2^{\text {nd }}$ edn. İstanbul: Nobel Tip Kitabevleri, 2008;3-14. (in Turkish)

3. Yurdakök M, Erdem G. Prematurity. Neonatology. Ankara: Turkish Neonatology Association, 2004;119-24. (in Turkish)

4. Erdeve Ö, Atasay B, Arsan S, Türmen T. Effects of the hospitalization experience in the neonatal intensive care unit on the family and premature infant. J Child Health Dis. 2008;51: 104-9.

5. Liu CC, Chen YC, Yeh YP, Hsieh YS. Effects of maternal confidence and competence on maternal parenting stress in newborn care. J Adv Nurs. 2012;68:908-18, http://dx.doi. org/10.1111/j.1365-2648.2011.05796.x

6. Boztepe H, Çavuşoğlu H. Examination of a family centered care practice at the children's units of a university hospital.J Hacettepe Univ School of Nurs. 2009;16(1):11-24. (in Turkish)

7. Çalışır H, Şeker S, Güler F, Taşcıŏlu AG, Türkmen M. The anxiety levels and needs of infants' parents in a neonatal intensive care unit. Cumhuriyet Univ J School Nurs. 2008;12:31-44. (in Turkish)

8. Johnson AN. Promoting maternal confidence in the NICU. J Pediatr Health Care. 2008;22(4):254-7, http://dx.doi.org/ 10.1016/j.pedhc.2007.12.012 
9. Horn VE, Tesh A. The effect of critical care hospitalization on family members: stress and responses. Dimens Crit Care Nurs. 2000;19(4):40-9, http://dx.doi.org/10.1097/00003465-200019040-00014

10. Valizadeh L, Zamanzadeh V, Akbarbegloo M, Sayadi L. Importance and availability of nursing support for mothers in NICU: a comparison of opinions of Iranian mothers and nurses. Iran J Pediatr. 2012:22(2);191-6.

11. Kurnaz E. Concerns and care requirements of mothers with babies held in neonatal intensive care unit. Master Thesis, Marmara University, İstanbul, Turkey, 2007. (in Turkish)

12. Çavusoğlu H. The effects of hospitalization on the child and family. Child Health Nursing, Vol. 1, $12^{\text {th }}$ edn. Ankara: Sistem Ofset Basımevi, 2015;53-54. (in Turkish)

13. Reck C, Noe D, Gerstenlauer J, Stehle E. Effects of postpartum anxiety disorders and depression on maternal self-confidence. Infant Behav Dev. 2012;35:264-72, http://dx.doi.org/10.1016/j.infbeh.2011.12.005

14. Cleveland LM. Parenting in the neonatal intensive care unit. J Obstet Gynecol Neonatal Nurs. 2008;37:666-91, http://dx. doi.org/10.1111/j.1552-6909.2008.00288.x

15. Obeidat HM, Bond AE, Callister LC. The parental experience of having an infant in the newborn intensive care unit. J Perinat Educ. 2009;18(3):23-9, http://dx.doi.org/10.1624/105812409X461199

16. Forcada-Guex M, Pierrehumbert B, Borghini A, Moessinger A, Muller-Nix C. Early dyadic patterns of mother-infant interactions and outcomes of prematurity at 18 months. Pediatrics. 2006;118:e107-e114, http://dx.doi.org/10.1542/peds.2005-1145

17. Melnyk BM, Crean HF, Feinstein NF, Fairbanks E. Maternal anxiety and depression after a premature infant's discharge from the neonatal intensive care unit: explanatory effects of the creating opportunities for parent empowerment program. Nurs Res. 2008;57:383-94, http://dx.doi.org/10.1097/NNR.0b013e3181906f59
18. Gözüm S, Aksayan S. A guide for transcultural adaptation of the scale II: Psychometric characteristics and cross-cultural comparison. J Res Dev Nurs. 2003;5(1):3-14. (in Turkish)

19. Şencan H. Reliability and validity in social and behavioral measurements, $1^{\text {st }}$ edn. Ankara, Seçkin Yayınevi, 2005;107-13, 166-9, 381-90. (in Turkish)

20. Melnyk BM, Oswalt KL, Sidora-Arcoleo K. Validation and psychometric properties of the Neonatal Intensive Care Unit Parental Beliefs Scale. Nurs Res. 2014;63(2):105-15, http:// dx.doi.org/10.1097/NNR.0000000000000023

21. Lovko SK, Gelo J, Karlović D. Validation study of the Toronto Alexithymia Scale (TAS-26) in Croatian population. Acta Clin Croat. 2015;54:272-8.

22. Leahy-Warren P, McCarthy G, Corcoran P. First-time mothers: social support, maternal parental self-efficacy and postnatal depression. J Clin Nurs. 2012;21:388-97, http://dx.doi.org/10.1111/j.1365-2702.2011.03701.x

23. Heidari H, Hasanpour M, Fooladi M. The experiences of parents with infants in Neonatal Intensive Care Unit. Iran J Nurs Midwifery Res. 2013;18(3):208-13.

24. Ercan İ, Kan İ. Reliability and validity in scales. Uludağ Univ Fac Med J. 2004;30(3):211-6.

25. Çam MO, Arabacı LB. Qualitative and quantitative steps on attitude scale construction. J Res Dev Nurs. 2010;2:59-71. (in Turkish)

26. Jackson DL, Gillaspy JA Jr, Purc-Stephenson R. Reporting practices in confirmatory factor analysis: an overview and some recommendations. Psychol Methods. 2009;14:6-23. http://dx. doi.org/10.1037/a0014694

27. Bornstein MH, Cote LR, Haynes OM, Hahn CS, Park Y. Parenting knowledge: experiential and sociodemographic factors in European American mothers of young children. Dev Psychol. 2010;46:1677-93. http://dx.doi.org/10.1037/ a0020677

Sažetak

\section{VALJANOST I POUZDANOST LJESTVICE RODITELJSKIH UVJERENJA U VEZI S NEONATALNOM JEDINICOM INTENZIVNOG LIJEČENJA ZA RODITELJE U TURSKOJ}

\section{F. Kardaş Özdemir i D. Küçük Alemdar}

Ovo metodološko istraživanje provedeno je za tursku prilagodbu Ljestvice roditeljskih uvjerenja u vezi s neonatalnom jedinicom intenzivnog liječenja (NICU PBS). Ispitivani uzorak činilo je 136 majki i 97 očeva koji su dali suglasnost za sudjelovanje u istraživanju. Jezičnu valjanost ljestvice ispitali su turski lingvisti. Provedena je analiza eksplanatornih čimbenika za valjanost konstrukta ljestvice te je kao rezultat analize čimbenika utvrđeno da 18 stavaka ljestvice ima strukturu od tri čimbenika, što je objasnilo najviše $70,24 \%$ ukupne varijance. Prema snazi čimbenika utvrđeno je da se vrijednosti snage čimbenika kreću od 0,614 do 0,806. Za pouzdanost ljestvice vrijednosti korelacije stavki i ukupnog zbira bile su 0,54-0,78, a Cronbach alfa 0,90. Dakle, turska inačica NICU PBS može se smatrati valjanom i pouzdanom.

Ključne riječi: Jedinice za intenzivnu skrb, neonatalne; Roditeljski odgoj-psibologija; Reproducibilnost rezultata; Ankete i upitnici; Turska 